\title{
Evaluation of stress tolerance of Azotobacter isolates
}

\author{
Navin Kumar Nag1, \\ Biplab Dash ${ }^{1}$, \\ Shyam Bihari Gupta ${ }^{1}$, \\ Dharmendra Khokher², \\ Ravindra Soni ${ }^{1}$ \\ ${ }^{1}$ Department of Agricultural Microbiology, \\ College of Agriculture, \\ IGKV, Raipur (C.G.), India \\ ${ }^{2}$ Department of Plant Physiology, \\ Agricultural Biochemistry, \\ Medicinal and Aromatic Plants, \\ College of Agriculture, \\ IGKV, Raipur (C.G), India
}

\begin{abstract}
Evaluation of 50 Azotobacter isolates was done for tolerance to $\mathrm{pH}$, high temperature, and salinity, and four isolates (Azo-48, Azo-137, Azo-144, and Azo-160) passed all three tests. Tolerance to $\mathrm{pH}$ (5.0) was shown by a large quota of 20 isolates, while most of them (75\%) also showed temperature-tolerance ability. Analysis of colony characteristics, biochemical properties, nitrogen fixing capacity, and phytohormone production of 14 selected isolates was carried out. Finally, after an extensive evaluation and critical analysis, we were able to sort out the above-mentioned four isolates and one of them (Azo-144) exhibited tolerance to a reasonably high degree of salinity stress.
\end{abstract}

Keywords: stress, Azotobacter, tolerance, bio-fertilizers

\section{INTRODUCTION}

Biofertilisers are of paramount importance in agricultural production as they facilitate proportionate distribution of nutrients to plants (Wani et al., 2013). They are indeed a living entity that, when inoculated into the soil, helps in genesis of boundless beneficial microbes. In extreme climatic conditions like high and low temperatures, a high $\mathrm{pH}$, etc., where crop production is extremely difficult, these microbes help in enhancing crop productivity without compromising the soil fertility status. Keeping this fact in mind, the main obstacle facing us lies in screening and isolation of stress-tolerant microbes. For development of an ideal microbial consortium capable of tackling a high degree of abiotic stress, our prime target should be well orchestrated in order to evaluate those microbes.

\footnotetext{
* Corresponding author. Email: rs31693@gmail.com
}

In this sphere, some notable contributions have been made all over the globe by numerous researchers. For example, Kumar et al. (2014) identified several strains of Pseudomonas and Bacillus showing tolerance to high temperature $\left(50^{\circ} \mathrm{C}\right)$ and salinity $\left(14 \times 10^{2} \mathrm{dS} / \mathrm{m}\right)$; four bacterial strains of Pseudomonas frederiksbergensis OS211, Flavobacteriumglaciei OB146, Pseudomonas vancouverensis OB155, and Pseudomonas frederiksbergensis OS261 were found effective in countering chilling stress on the tomato plant by Subramanian et al. (2016). Similarly, Orhan (2016) evaluated 18 bacterial isolates for halophilic and halotolerant capability in the wheat plant under hydroponic conditions.

Azotobacter is an aerobic and free-living bacterium widely distributed throughout the world and characterised by an added advantage of nitrogen-fixation (Becking, 1981; Balow et al., 1979). Moreover, its propensity to utilise a wide array of substrates containing carbohydrates (Lineweaver, 1933), alcohols (Gomare et al., 2013), and organic 
acids (Wu et al., 1987) as a source of carbon augmented with several metabolic capabilities makes it an indispensible choice for scientists in the domain of biofertilizer research. Adding to its ability of potent nitrogen fixation by non-symbiotic means (Tejera et al., 2005), it is also noteworthy to mention that it has the highest metabolic rate among all organisms. Regardless of its vital and imperative nature in agriculture, the extent of its usage is still low due to its sensitiveness to acute abiotic stresses such as high temperature (Hogg, 2005), acidic pH (Raju et al., 1974; Khullar, Chahal, 1975), and high salinity (Ninawe, Paulraj, 2003). Therefore our approach in this experiment is subjected towards the evaluation of effective Azotobacter isolates competent enough for giving expected performance and withstanding harsh conditions of abiotic stress.

\section{MATERIALS AND METHODS}

\section{Culture retrieval}

Azotobacter slants were taken from the collection of the Department of Agricultural Microbiology under Indira Gandhi Krishi Viswavidhyalaya located at Raipur, Chhattisgarh, India. A total of 50 cultures were then revived by streaking them on Petri plates containing Jensen's medium having a $\mathrm{pH}$ 7.0; this was followed by incubation at $28^{\circ} \mathrm{C}$ in an incubator for $48-72$ hours. Single distinctive bacterial colonies were then taken and inoculated in tube slants consisting of Jensen medium for further use.

\section{Colony characteristics}

Characteristics of all isolates were determined as per Bergey's Manual of Systematic Bacteriology (2001). The type of shape, arrangement of cells, and their Gram reaction were elaborately studied. Later on, after development of colonies was done on the ideal medium through streaking, a thorough examination of morphological characteristics (form, colour, elevation, margin, consistency) was carried out.

\section{Biochemical analysis}

The isolates were characterized using standard biochemical methods as given in Bergey's Man- ual of Systematic Bacteriology (2001). A series of biochemical test were done for selected 14 bacterial isolates after meticulous screening for $\mathrm{pH}$ and temperature tolerance capability in order to further determine their distinctive biochemical properties. The catalase test, the acid production test, the starch hydrolysis test, Winogradsky test, the urease production test, and the pigment test in iron-deficient medium were carried out. A very specialized test - the Triple Sugar Iron Agar test - was conducted in order to diagnose them for glucose, lactose, and sucrose fermentation along with peptone catabolization, gas and $\mathrm{H}_{2} \mathrm{~S}$ production ability.

\section{Screening for $\mathrm{pH}$, temperature, and salt tolerance}

All the 50 cultures of Azotobacter isolates were grown in Jensen's medium on Petri plates with a range of $\mathrm{pH}$ of 5.0, 5.5, 6.0, 7.0, and 8.0. These plates were then incubated in an incubator at $28^{\circ} \mathrm{C}$ for a period of 48 to 72 hours. Based on their nature and the type of growth on the entire span of $\mathrm{pH}$ arrays, these isolates were screened for $\mathrm{pH}$ tolerance. The bacterial isolates were screened for temperature tolerance at distinct temperatures beginning at $28^{\circ} \mathrm{C}, 37^{\circ} \mathrm{C}, 40^{\circ} \mathrm{C}$, $45^{\circ} \mathrm{C}, 50^{\circ} \mathrm{C}$, and ending at higher temperatures of $55^{\circ} \mathrm{C}$ and $60^{\circ} \mathrm{C}$. The cultures were first inoculated in a $5 \mathrm{ml}$ Jensen's broth tube which were taken from the log phase culture and were subsequently incubated for $48-72$ hours at $28^{\circ} \mathrm{C}$. After appropriate growth in these tubes was observed, they were further incubated at respective above-mentioned temperatures for $30 \mathrm{~min}$. To finally ascertain their growth, $100 \mu \mathrm{l}$ of broth culture from each tube were then spread on agar plates containing Jensen's media and allowed for growing at $28^{\circ} \mathrm{C}$ for $48-72$ hours. Signs of promising growth shown by isolates for temperature tolerance against control were selected. Azotobacter isolates were inoculated on $5 \mathrm{ml}$ nutrient broth medium with $\mathrm{NaCl}$ salt of $0 \%, 2 \%, 5 \%$, and $10 \%$ concentration. It was then incubated at $28^{\circ} \mathrm{C}$ for $48-72$ hours. Upon development of satisfactory growth at different concentrations of $\mathrm{NaCl}$, they were compared with control for their salt tolerance capability. 
Nitrogen-fixing capacity of Azotobacter isolates in pure culture

Establishing of $\mathrm{N}_{2}$ fixing capacity of Azotobacter isolates was done by the micro-Kjeldhal method of Bergersen, 1980. Firstly, the isolates were allowed to grow in semisolid $\mathrm{N}_{2}$-free Jensen's medium supplemented with L-glutamic acid $(100 \mathrm{mg} / \mathrm{l})$ and incubated for five days at a temperature of $28^{\circ} \mathrm{C}$. Then $5 \mathrm{ml}$ of well-homogenised culture were taken and digested with $5 \mathrm{ml}$ concentrated $\mathrm{H}_{2} \mathrm{SO}_{4}$ along with 5 grams of digestion mixture $\left(\mathrm{K}_{2} \mathrm{SO}_{4}\right.$ and $\mathrm{CuSO}_{4}$ in a ratio of 10:1) until the content was clear enough. Following cooling, $5 \mathrm{ml}$ of aliquot was then transferred into a micro-Kjeldhal distillation unit and $10 \mathrm{ml}$ of $40 \% \mathrm{NaOH}$ was added, after which the distillation process was carried out. Upon completion, ammonia gas produced was collected in a conical flask containing $10 \mathrm{ml}$ of $2 \%$ boric acid dissolved in mixed indicator $(83.3 \mathrm{mg}$ bromocresol green and $16.6 \mathrm{mg}$ methyl red indicator dissolved in $10 \mathrm{ml}$ of $95 \%$ alcohol) and titrated against $0.005 \mathrm{~N}_{2} \mathrm{SO}_{4}$. Using titre value and the formula of $1 \mathrm{ml}$ of $0.005 \mathrm{~N} \mathrm{H}_{2} \mathrm{SO}_{4}=0.00007 \mathrm{~g}$ of $\mathrm{N}$, the nitrogen fixed in vitro was calculated and expressed in $\mathrm{N}$ fixed/g of malate supplied.

Calculation:

(sample titre - blank titre) $\times$ normality of standard $\times 14.007$

nitrogen content $(\mathrm{mg})=$ sample weight $(\mathrm{gram})$

\section{Production of phytohormones}

Estimation of IAA (indole acetic acid) production potential of selected bacterial isolates was tested in Jensen's or Bark's $\mathrm{N}_{2}$-free broth further supplemented with $0.005 \mathrm{M}$ tryptophan at $28^{\circ} \mathrm{C}$. After an incubation of three days, the concentration of IAA in culture broth was established by the spectrophotometric method using Salkowski reagent. $1.5 \mathrm{ml}$ of culture supernatant was mixed with $1 \mathrm{ml}$ of Salkowski reagent. The amount of red colour intensity developed within $30 \mathrm{~min}$ utes and was checked at $530 \mathrm{~nm}$ using a scanning spectrophotometer. A standard curve was prepared from a standard solution of indole acetic acid (Mali and Bodhankar, 2009) for determining the concentration of IAA. In addition to this, the potential of isolates to produce gibberellins was also determined. The isolates were made to grow in Jensen's nitrogen-free broth at $28^{\circ} \mathrm{C}$ and incubated for three days after which the amount of gibberellins produced was estimated through the spectrophotometric method as described by Mali and Bodhankar, 2009.

\section{RESULTS AND DISCUSSION}

\section{Screening of Azotobacter isolates for $\mathrm{pH}$ tolerance}

All the 50 bacterial isolates showed encouraging positive growth at a neutral $\mathrm{pH}$ (7.0) from which we can infer that this is the epitome of $\mathrm{pH}$ for appropriate growth of all the bacterial isolates even though almost all of them, with the exception of nine (Azo-26, Azo-27, Azo-45, Azo-89, Azo-123, Azo-126, Azo-127, Azo-145, Azo149), also grew at $\mathrm{pH}$ 8.0. In other words, these nine are the isolates that failed to grow on any other $\mathrm{pH}$ except the neutral one. The growth of some isolates started decreasing gradually as we progressed forward towards the acidic $\mathrm{pH}$ range thus showing their intolerance towards acidic medium and, in a way, giving us a chance for deciphering those tolerant isolates out of the pool of 50 isolates. Out of the remaining 41 isolates, seven of them (Azo-15, Azo-51, Azo-98, Azo-109, Azo-115, Azo-122, Azo-146) exhibited growth within $\mathrm{pH}$ range of 6.0 to 8.0 , whereas only one isolate (Azo-65) grew at the $\mathrm{pH}$ 5.5. Meanwhile, as many as 20 isolates (Azo-18, Azo-32, Azo33, Azo-35, Azo-38, Azo-47, Azo-48, Azo-91, Azo-108, Azo-121, Azo-125, Azo-129, Azo-133, Azo-137, Azo-144, Azo-154, Azo-156, Azo-160, Azo-162) succeeded in reaching the 5.0 stage, henceforth imprinting their ability to grow on a wide range of $\mathrm{pH}$ (5.0 to 8.0) (Table 1).

\section{Screening of Azotobacter isolates for tem- perature tolerance}

Transition in the temperature range has a profound impact on growth and development of Azotobacter bacteria which can be distinctly seen in the Table 2. Having perceived from our experiment that the ideal temperature for growth of all Azotobacter isolates is $28^{\circ} \mathrm{C}$, from 
Table 1. Screening of Azotobacter isolates for $\mathbf{p H}$ tolerance

\begin{tabular}{|c|c|c|c|c|c|c|}
\hline No. & Isolates & pH 5.0 & pH 5.5 & pH 6.0 & pH 7.0 & pH 8.0 \\
\hline 1. & Azo-11 & - & - & - & + & + \\
\hline 2. & Azo-15 & - & - & + & + & + \\
\hline 3. & Azo-18 & + & + & + & + & + \\
\hline 4. & Azo-23 & - & - & - & + & + \\
\hline 5. & Azo-24 & - & - & - & + & + \\
\hline 6. & Azo-25 & - & - & - & + & + \\
\hline 7. & Azo-26 & - & - & - & + & - \\
\hline 8. & Azo-27 & - & - & - & + & - \\
\hline 9. & Azo-28 & - & - & - & + & + \\
\hline 10. & Azo-32 & + & + & + & + & + \\
\hline 11. & Azo-33 & + & + & + & + & + \\
\hline 12. & Azo-34 & - & - & - & + & + \\
\hline 13. & Azo-35 & + & + & + & + & + \\
\hline 14. & Azo-38 & + & + & + & + & + \\
\hline 15. & Azo-39 & - & - & - & + & + \\
\hline 16. & Azo-40 & - & - & - & + & + \\
\hline 17. & Azo-44 & - & - & - & + & + \\
\hline 18. & Azo-45 & - & - & - & + & - \\
\hline 19. & Azo-46 & - & - & - & + & + \\
\hline 20. & Azo-47 & + & + & + & + & + \\
\hline 21. & Azo-48 & + & + & + & + & + \\
\hline 22 & Azo-51 & - & - & + & + & + \\
\hline 23. & Azo-58 & - & - & - & + & + \\
\hline 24. & Azo-65 & - & + & + & + & + \\
\hline 25. & Azo-83 & - & - & - & + & + \\
\hline 26. & Azo-89 & - & - & - & + & - \\
\hline 27. & Azo-91 & + & + & + & + & + \\
\hline 28. & Azo-98 & - & - & + & + & + \\
\hline 29. & Azo-108 & + & + & + & + & + \\
\hline 30. & Azo-109 & - & - & + & + & + \\
\hline 31. & Azo-115 & - & - & + & + & + \\
\hline 32. & Azo-121 & + & + & + & + & + \\
\hline 33. & Azo-122 & - & - & + & + & + \\
\hline 34. & Azo-123 & - & - & - & + & - \\
\hline 35. & Azo-125 & + & + & + & + & + \\
\hline 36. & Azo-126 & - & - & - & + & - \\
\hline 37. & Azo-127 & - & - & - & + & - \\
\hline 38. & Azo-129 & + & + & + & + & + \\
\hline 39. & Azo-133 & + & + & + & + & + \\
\hline 40. & Azo-137 & + & + & + & + & + \\
\hline 41. & Azo-144 & + & + & + & + & + \\
\hline 42. & Azo-145 & + & + & + & + & - \\
\hline
\end{tabular}


Table 1. (Continued)

\begin{tabular}{ccccccccc}
\hline No. & Isolates & pH 5.0 & pH 5.5 & pH 6.0 & pH 7.0 & pH 8.0 \\
\hline 43. & Azo-146 & - & - & + & + & + \\
\hline 44. & Azo-149 & - & - & - & + & + \\
\hline 45. & Azo-154 & + & + & + & + & + \\
\hline 46. & Azo-155 & - & - & - & + & + & + \\
\hline 47. & Azo-156 & + & + & + & + & + \\
\hline 48. & Azo-159 & - & + & + & + & + \\
\hline 49. & Azo-160 & + & + & + & + & + \\
\hline 50. & Azo-162 & + & + & + & + \\
\hline
\end{tabular}

Table 2. Screening of Azotobacter isolates for temperature tolerance

\begin{tabular}{|c|c|c|c|c|c|c|c|c|}
\hline \multirow[b]{2}{*}{ No. } & \multirow[b]{2}{*}{ Isolates } & \multicolumn{7}{|c|}{ Temperature, ${ }^{\circ} \mathrm{C}$} \\
\hline & & $28^{\circ} \mathrm{C}$ & $37^{\circ} \mathrm{C}$ & $40^{\circ} \mathrm{C}$ & $45^{\circ} \mathrm{C}$ & $50^{\circ} \mathrm{C}$ & $55^{\circ} \mathrm{C}$ & $60^{\circ} \mathrm{C}$ \\
\hline 1. & Azo-11 & + & + & + & - & - & - & - \\
\hline 2. & Azo-15 & + & + & + & + & + & + & + \\
\hline 3. & Azo-18 & + & + & + & + & + & + & + \\
\hline 4. & Azo-23 & + & - & - & - & - & - & - \\
\hline 5. & Azo-24 & + & - & - & - & - & - & - \\
\hline 6. & Azo-25 & + & - & - & - & - & - & - \\
\hline 7. & Azo-26 & + & - & - & - & - & - & - \\
\hline 8. & Azo-27 & + & - & - & - & - & - & - \\
\hline 9. & Azo-28 & + & - & - & - & - & - & - \\
\hline 10. & Azo-32 & + & + & + & + & + & + & + \\
\hline 11. & Azo-33 & + & + & + & + & + & + & + \\
\hline 12. & Azo-34 & + & + & + & + & + & - & - \\
\hline 13. & Azo-35 & + & + & + & + & + & + & + \\
\hline 14. & Azo-38 & + & + & + & + & + & + & + \\
\hline 15. & Azo-39 & + & - & - & - & - & - & - \\
\hline 16. & Azo-40 & + & - & - & - & - & - & - \\
\hline 17. & Azo-44 & + & - & - & - & - & - & - \\
\hline 18. & Azo-45 & + & - & - & - & - & - & - \\
\hline 19. & Azo-46 & + & - & - & - & - & - & - \\
\hline 20. & Azo-47 & + & + & + & + & + & + & + \\
\hline 21. & Azo-48 & + & + & + & + & + & + & + \\
\hline 22 & Azo-51 & - & - & + & + & + & + & - \\
\hline 23. & Azo-58 & + & - & - & - & - & - & - \\
\hline 24. & Azo-65 & + & + & + & + & + & + & + \\
\hline 25. & Azo-83 & + & - & - & - & - & - & - \\
\hline 26. & Azo-89 & + & - & - & - & - & - & - \\
\hline 27. & Azo-91 & + & + & + & + & + & + & + \\
\hline 28. & Azo-98 & + & + & - & - & - & - & - \\
\hline 29. & Azo-108 & + & + & + & + & + & - & - \\
\hline
\end{tabular}


Table 2. (Continued)

\begin{tabular}{|c|c|c|c|c|c|c|c|c|}
\hline \multirow[b]{2}{*}{ No. } & \multirow[b]{2}{*}{ Isolates } & \multicolumn{7}{|c|}{ Temperature, ${ }^{\circ} \mathrm{C}$} \\
\hline & & $28^{\circ} \mathrm{C}$ & $37^{\circ} \mathrm{C}$ & $40^{\circ} \mathrm{C}$ & $45^{\circ} \mathrm{C}$ & $50^{\circ} \mathrm{C}$ & $55^{\circ} \mathrm{C}$ & $60^{\circ} \mathrm{C}$ \\
\hline 30. & Azo-109 & + & + & + & + & + & - & - \\
\hline 31. & Azo-115 & + & + & + & + & + & - & - \\
\hline 32. & Azo-121 & + & + & + & + & + & + & + \\
\hline 33. & Azo-122 & + & + & - & - & - & - & - \\
\hline 34. & Azo-123 & + & - & - & - & - & - & - \\
\hline 35. & Azo-125 & + & + & + & + & + & + & + \\
\hline 36. & Azo-126 & + & + & - & - & - & - & - \\
\hline 37. & Azo-127 & + & + & + & + & + & - & - \\
\hline 38. & Azo-129 & + & + & + & + & + & + & + \\
\hline 39. & Azo-133 & + & + & + & + & + & + & - \\
\hline 40. & Azo-137 & + & + & + & + & + & + & + \\
\hline 41. & Azo-144 & + & + & + & + & + & + & + \\
\hline 42. & Azo-145 & + & + & + & + & + & + & - \\
\hline 43. & Azo-146 & + & + & + & + & - & - & - \\
\hline 44. & Azo-149 & + & + & + & + & - & - & - \\
\hline 45. & Azo-154 & + & + & + & + & + & + & - \\
\hline 46. & Azo-155 & + & + & + & - & - & - & - \\
\hline 47. & Azo-156 & + & + & + & - & - & - & - \\
\hline 48. & Azo-159 & + & + & + & - & - & - & - \\
\hline 49. & Azo-160 & + & + & + & + & + & + & + \\
\hline 50. & Azo-162 & + & + & + & + & + & - & - \\
\hline
\end{tabular}

our experiment, it was not surprising to notice that the growth started to decrease progressively and ultimately ceased above that particular temperature. Having said that, 16 isolates (Azo-23, Azo-24, Azo-25, Azo-26, Azo-27, Azo-28, Azo39, Azo-40, Azo-44, Azo-45, Azo-46, Azo-51, Azo-58, Azo-83, Azo-89, Azo-123) stalled their growth at $37^{\circ} \mathrm{C}$, while three others (Azo-98, Azo122, Azo-126) miserably failed to survive $40^{\circ} \mathrm{C}$ and along with them four isolates (Azo-11, Azo155, Azo-156, Azo-159) broke down at $45^{\circ} \mathrm{C}$. In the course of our experiment, we observed a very peculiar and inconsistent behaviour in Azo-51: it grew within the range of $40^{\circ}$ to $50^{\circ} \mathrm{C}$, however, it showed no signs of growth below and above that range. Among the left out isolates, two isolates - Azo-146 and Azo-149 - were unsuccessful in reaching $50^{\circ} \mathrm{C}$, and isolates Azo-34, Azo-127, and Azo- 162 met the same fate at $55^{\circ} \mathrm{C}$. Finally, 16 isolates (Azo-15, Azo-18, Azo-32, Azo-33,
Azo-35, Azo-38, Azo-47, Azo-48, Azo-65, Azo91, Azo-121, Azo-125, Azo-129, Azo-137, Azo144 and Azo-160) remained in our collection that were able to tolerate the temperature as high as $60^{\circ} \mathrm{C}$. If we consider both the parameters $(\mathrm{pH}$ and temperature) from the angle of comparative vision, we will note an impressive correlation between them, that is, a 75\% similarity can be observed between the isolates showing tolerance to $\mathrm{pH}(5.0-8.0)$ and temperature $\left(28-60^{\circ} \mathrm{C}\right)$. There were 14 isolates of this kind which were selected for the remaining part of our experiment.

\section{Colony characteristics}

Colony morphology depicts the true nature of microorganisms. It is an imperative tool for their characterisation and an in-depth study of their behaviour in their natural habitat. The 14 selected isolates displayed negative reaction to Gram staining, possessing a circular form 
when viewed on Petri plates with their colony displaying an entire margin which concluded that Azotobacter is a Gram-negative bacterium. Some degree of variation was seen in bacterial growth with respect to their texture or consistency. Azo- 47 was showing a mucoid type texture while all other isolates showed gummy consistency, except Azo-32 and Azo-121, which were not gummy. Most of the isolates had a transparent colony, with few anomalies (Azo-33, Azo-47, Azo-144) revealing a translucent look. The colour of the colonies was in fact equally exchanged between them, with eight colonies displaying white colour while, in contrast to them, seven were showing off-white colour. Elevation of colony was mostly flat or convex type in the ratio of 8:7, respectively (Table 3 ).

\section{Biochemical tests}

A series of biochemical tests were carried out for a better understanding of the physiochemical functions going on within the cell. The hydrogen peroxide degrading enzyme catalase, which protects the cells from reactive oxygen species by converting it into water and oxygen, was present in all the selected 14 isolates. None of the isolates were found positive for utilising urea and starch due to the lack of urease and $a$-amylase enzyme, while all of them unambig- uously passed the acid production and Winogradsky tests. Azo-47, Azo-91, Azo-137, and Azo-160 grew confidently in an iron-deficient medium, while the rest proved their inability. The triple sugar iron test was used for deducing the ability of the microbes of fermenting different types of sugars (glucose, lactose, sucrose) and producing $\mathrm{H}_{2} \mathrm{~S}$ and other gases. We observed that only three (Azo-47, Azo-48, Azo144) of the 15 isolates succeeded in fermenting glucose, sucrose, and fructose, although two others (Azo-137, Azo-160) demonstrated ability of fermenting only glucose. Leaving behind only three isolates (Azo-47, Azo-48, and Azo144), the remaining 12 exhibited their capability for catabolising peptones. None of the isolates produced any gas or $\mathrm{H}_{2} \mathrm{~S}$ (Tables 4 and 5).

\section{Nitrogen-fixing capacity}

Azototobacter is a non-symbiotic, aerobic freeliving bacterium capable of nitrogen fixation in plants which are devoid of extracting available nitrogen from the soil environment. The Azotobacter isolate with the strongest nitrogen-producing ability was Azo-47, which demonstrated unrivalled performance of $11.2 \mathrm{mg}$ of nitrogen per gram of Jensen's medium. The whole spectrum of variation in nitrogen fixation ranged from the maximum of 11.2 to the minimum of

Table 3. Colony characteristics

\begin{tabular}{ccccccccccc}
\hline No. & Isolates & Gram stain & Form & Colour & Elevation & Margin & Consistency & Density \\
\hline 1. & Azo-18 & negative & circular & Off white & Convex & Entire & Gummy & Transparent \\
\hline 2. & Azo-32 & negative & circular & white & flat & entire & not gummy & transparent \\
\hline 3. & Azo-33 & negative & circular & white & flat & entire & gummy & not transparent \\
\hline 4. & Azo-35 & negative & circular & white & flat & entire & gummy & transparent \\
\hline 5. & Azo-38 & negative & circular & white & convex & entire & gummy & transparent \\
\hline 6. & Azo-47 & negative & circular & white & flat & entire & mucoid & not transparent \\
\hline 7. & Azo-48 & negative & circular & off white & flat & entire & gummy & transparent \\
\hline 8. & Azo-91 & negative & circular & off white & convex & entire & gummy & transparent \\
\hline 9. & Azo-121 & negative & circular & off white & flat & entire & not gummy & transparent \\
\hline 10. & Azo-125 & negative & circular & off white & convex & entire & gummy & transparent \\
\hline 11. & Azo-129 & negative & circular & white & flat & entire & gummy & transparent \\
\hline 12. & Azo-137 & negative & circular & off white & convex & entire & gummy & transparent \\
\hline 13. & Azo-144 & negative & circular & off white & convex & entire & gummy & not transparent \\
\hline 14. & Azo-160 & negative & circular & white & convex & entire & gummy & transparent \\
\hline
\end{tabular}


Table 4. Biochemical tests

\begin{tabular}{|c|c|c|c|c|c|c|c|}
\hline $\begin{array}{c}\text { Serial } \\
\text { No. }\end{array}$ & Isolate No. & Catalase & $\begin{array}{c}\text { Starch hy- } \\
\text { drolysis }\end{array}$ & $\begin{array}{l}\text { Iron defi- } \\
\text { cient }\end{array}$ & $\begin{array}{l}\text { Acid pro- } \\
\text { duction }\end{array}$ & $\begin{array}{c}\text { Winograd- } \\
\text { sky }\end{array}$ & Urease broth \\
\hline 1. & Azo-18 & + & - & - & + & + & - \\
\hline 2. & Azo-32 & + & - & - & + & + & - \\
\hline 3. & Azo-33 & + & - & - & + & + & - \\
\hline 4. & Azo-35 & + & - & - & + & + & - \\
\hline 5. & Azo-38 & + & - & - & + & + & - \\
\hline 6. & Azo-47 & + & - & + & + & + & - \\
\hline 7. & Azo-48 & + & - & - & + & + & - \\
\hline 8. & Azo-91 & + & - & + & + & + & - \\
\hline 9. & Azo-121 & + & - & - & + & + & - \\
\hline 10. & Azo-125 & + & - & - & + & + & - \\
\hline 11. & Azo-129 & + & - & - & + & + & - \\
\hline 12. & Azo-137 & + & - & + & + & + & - \\
\hline 13. & Azo-144 & + & - & - & + & + & - \\
\hline 14. & Azo-160 & + & - & + & + & + & - \\
\hline
\end{tabular}

Table 5. Triple sugar iron test

\begin{tabular}{|c|c|c|c|c|c|c|c|}
\hline $\begin{array}{l}\text { Serial } \\
\text { No. }\end{array}$ & $\begin{array}{c}\text { Isolate } \\
\text { No. }\end{array}$ & $\begin{array}{l}\text { Glucose fer- } \\
\text { mentation }\end{array}$ & $\begin{array}{l}\text { Lactose fer- } \\
\text { mentation }\end{array}$ & $\begin{array}{c}\text { Sucrose fer- } \\
\text { mentation }\end{array}$ & $\begin{array}{l}\text { Peptone cat- } \\
\text { abolization }\end{array}$ & $\begin{array}{l}\text { Gas produc- } \\
\text { tion }\end{array}$ & $\begin{array}{c}\mathrm{H}_{2} \mathrm{~S} \text { produc- } \\
\text { tion }\end{array}$ \\
\hline 1. & Azo-18 & - & - & - & + & - & - \\
\hline 2. & Azo-32 & - & - & - & + & - & - \\
\hline 3. & Azo-33 & - & - & - & + & - & - \\
\hline 4. & Azo-35 & - & - & - & + & - & - \\
\hline 5. & Azo-38 & - & - & - & + & - & - \\
\hline 6. & Azo-47 & + & + & + & - & - & - \\
\hline 7. & Azo-48 & + & + & + & - & - & - \\
\hline 8. & Azo-91 & - & - & - & + & - & - \\
\hline 9. & Azo-121 & - & - & - & + & - & - \\
\hline 10. & Azo-125 & - & - & - & + & - & - \\
\hline 11. & Azo-129 & - & - & - & + & - & - \\
\hline 12. & Azo-137 & + & - & - & + & - & - \\
\hline 13. & Azo-144 & + & + & + & - & - & - \\
\hline 14. & Azo-160 & + & - & - & + & - & - \\
\hline
\end{tabular}

2.8 by Azo-18. Concurrently, six out of 14 isolates crossed the convincing figure of above 8 , which was observed in the case of two isolates (Azo-91 and Azo-144, with $8.4 \mathrm{mg} / \mathrm{g}$ capacity), while other three (Azo-32, Azo-33, and Azo137) fixing $9.8 \mathrm{mg} / \mathrm{g}$ remained behind Azo-47 (Figure).

\section{Production of phytohormones}

Phytohormones, like auxins and gibberellins produced by plants, are well known but it is really interesting to know that they, too, are produced by microbes, in particular bacteria. These hormones serve as plant growth-promoting agents by enhancing root and shoot development 


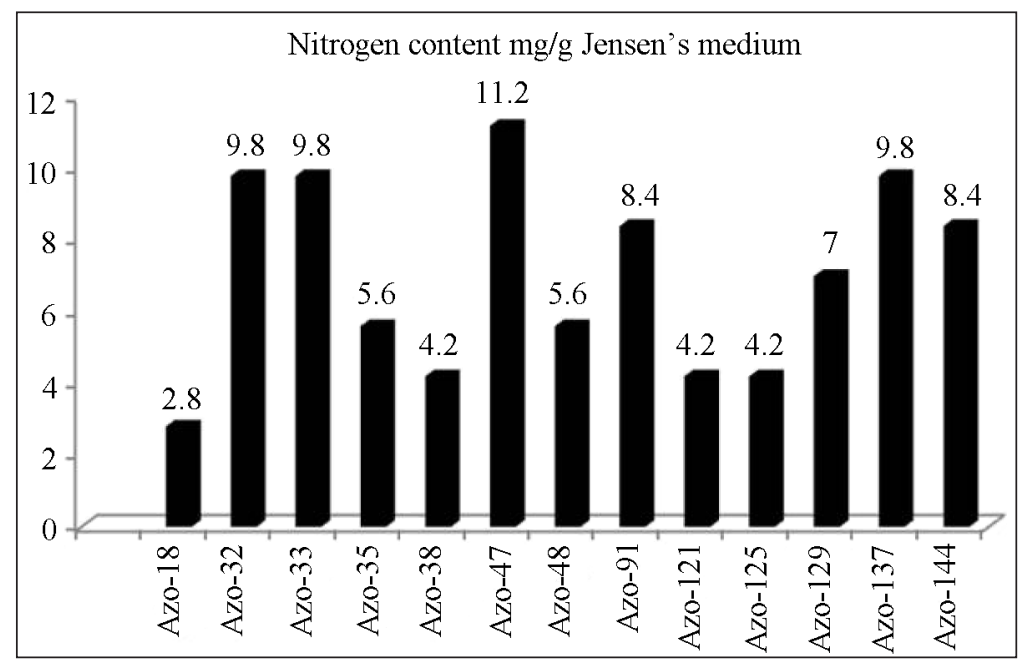

Figure. Nitrogen-fixing capacity

besides acting as anti-pathogenic agents. We found in our work that along with Azo-137, three other isolates (Azo-48, Azo-144 and Azo-160) produced indole acetic acid (IAA) in significant concentrations, but the performers to watch out for were Azo-137 and Azo-48. With OD value at $530 \mathrm{~nm}$ in a single-beam spectrophotometer, it was revealed that Azo-137 produced $96.35 \mu \mathrm{g} /$ $\mathrm{ml}$ of IAA beating Azo-48 by a difference of 8.2. Intriguingly, after finding some encouraging results, we decided to check these four isolates (Azo-48, Azo-137, Azo-144, Az0-160) for their

Table 6. Production of phytohormones

\begin{tabular}{c|cccc}
\hline No. & Isolate No. & $\begin{array}{c}\text { Indole ace- } \\
\text { tic acid }\end{array}$ & Gibberellin \\
\hline 1. & Azo-18 & - & - \\
\hline 2. & Azo-32 & - & - \\
\hline 3. & Azo-33 & - & - \\
\hline 4. & Azo-35 & - & - \\
\hline 5. & Azo-38 & - & - \\
\hline 6. & Azo-47 & - & - \\
\hline 7. & Azo-48 & + & - \\
\hline 8. & Azo-91 & - & - \\
\hline 9. & Azo-121 & - & - \\
\hline 10. & Azo-125 & - & - \\
\hline 11. & Azo-129 & - & - \\
\hline 12. & Azo-137 & + & - \\
\hline 13. & Azo-144 & + & - \\
\hline 14. & Azo-160 & + & \\
\hline
\end{tabular}

salinity tolerance based on the fact that there was some correlation between the amount of phytohormones produced with salinity tolerance, both by bacteria and plant (Tables 6 and 7).

\section{Screening of Azotobacter isolates for salt tolerance}

An extensive study was conducted for screening these four isolates at different levels of $\mathrm{NaCl}$ concentration. At $2 \%$ level, all four passed the test with flying colours, but the real challenge lied ahead when they were grown in $5 \%$ and $10 \%$ salinity

Table 7. Concentration of phytohormones produced

\begin{tabular}{c|c|c|c}
\hline No. & Isolate No. & $\begin{array}{c}\text { OD at } \\
\mathbf{5 3 0} \mathbf{~ n m}\end{array}$ & $\begin{array}{c}\text { Conc. of IAA in } \\
\boldsymbol{\mu g} / \mathbf{m l}\end{array}$ \\
\hline 1. & Azo-48 & 0.346 & 88.15 \\
\hline 2. & Azo-137 & 0.378 & 96.35 \\
\hline 3. & Azo-144 & 0.136 & 34.04 \\
\hline 4. & Azo-160 & 0.146 & 36.87 \\
\hline
\end{tabular}

Table 8. Screening of Azotobacter isolates for salt tolerance

\begin{tabular}{c|c|c|c|c|c}
\hline $\begin{array}{c}\text { Serial } \\
\text { No. }\end{array}$ & $\begin{array}{c}\text { Isolated } \\
\text { No. }\end{array}$ & $\begin{array}{c}\mathbf{0 \%} \\
\mathrm{NaCl}\end{array}$ & $\begin{array}{c}\mathbf{2} \% \\
\mathrm{NaCl}\end{array}$ & $\begin{array}{c}\mathbf{5 \%} \\
\mathrm{NaCl}\end{array}$ & $\begin{array}{c}\mathbf{1 0} \% \\
\mathbf{N a C l}\end{array}$ \\
\hline 1. & Azo-48 & + & + & - & - \\
\hline 2. & Azo-137 & + & + & - & - \\
\hline 3. & Azo-144 & + & + & + & - \\
\hline 4. & Azo-160 & + & + & - & - \\
\hline
\end{tabular}


mark, which only Azo-144 (at $5 \% \mathrm{NaCl}$ ) managed to cross. The other three isolates miserably failed to grow beyond the $2 \%$ level $\mathrm{NaCl}$ (Table 8 ).

\section{DISCUSSION}

There has been a tactical shift in the climate of the earth since the onset of the twenty-first century and the two great major causes are environmental pollution and exorbitantly high population. They complement each other in the phenomenon called global warming. The aftermath of such things correlates directly with agricultural productivity in the shadow of an exponential jump in abiotic stresses like $\mathrm{pH}$, high temperature, and salinity. Nonetheless, these conditions also take a toll on microbes besides affecting plants directly (Kumar et al., 2014). Overall, all over the earth, around $40 \%$ of total surface accounts for the salinity problem affecting growth and productivity of plants at higher $\mathrm{pH}$ (Jadhav et al., 2010). Azotobacter sp. is well known to all researchers in the domain of biofertilizer research. A substantial bulk of study has been done in this bacterium endowed with multifarious qualities ranging from non-symbiotic nitrogen-fixing ability to potential use as a biofertilizer capable of plant growth promotion and synthesis of antibiotics and vitamins (Suliasih, 2013; Jiménez et al., 2011). Still, several constrains pose as a major hurdle in further research work, and one of them is its susceptivity to abiotic stresses like acidic $\mathrm{pH}$, high temperature, and salinity (Jnawali et al., 2015); however, several stress-tolerant strains and isolates have been identified. Several species of Azotobacter, such as A. chroococcum, $A$. berijerinkii, and $A$. vivelandii with enhanced capacity of salt tolerance of up to $35 \mathrm{~g} / \mathrm{l}$ have been reported by Ravikumar et al. (2004). Higher proline as well as malondialdehyde content in the rice plant inoculated with a novel isolate of A. vinellandii under $200 \mathrm{mM} \mathrm{NaCl}$ was observed by Sahoo et al. (2014). Drought tolerance ability was exploited by Viscardi et al. (2016) on the tomato plant shown by two strains of Azotobacter chroococcum (Strain 67B and 76A).

Our experiment found that the ideal $\mathrm{pH}$ and temperature required for proper growth of Azoto- bacter bacterium is a neutral $\mathrm{pH}(7.0)$ and a temperature of around $30^{\circ} \mathrm{C}$, and it was supported by Alsamowal et al. (2016). It was reported that majority of the isolates (75\%) showing $\mathrm{pH}$ tolerance at 5.0 were also found to tolerate a maximum temperature of $60^{\circ} \mathrm{C}$. Having said this, a virtual correlation can be established between these two factors or, in other words, it can be said that isolates showing tolerance towards $\mathrm{pH}$ have the capability to withstand a higher temperature. Similar findings were reported by Chennappa G. et al. (2014), where a strain of A. chroococcum was found to simultaneously tolerate a $\mathrm{pH}$ of 8.0 and a temperature of $45^{\circ} \mathrm{C}$. Jadhav et al. (2010) reported two Azotobacter isolates taken from different food samples that simultaneously tolerated a wide $\mathrm{pH}$ range (5.0-10.0) and a high temperature $\left(60^{\circ} \mathrm{C}\right)$. Nitrogen fixation is one of the inherent features of this bacterium and studies have shown that it can fix up to $15 \mathrm{mg}$ $\mathrm{N}$ per gram of glucose it had consumed (Sethi, Adhikary, 2012) besides fixing $20 \mathrm{~kg} \mathrm{~N} / \mathrm{ha}$ annually (Rahmayani et al., 2017). From the above findings, an Azotobacter isolate (Azo-47) was reported to have the potential not only to fix nitrogen $(11.2 \mathrm{mg} / \mathrm{g}$ of Jensen's medium utilised) efficiently but also was able to overcome high temperature $\left(60^{\circ} \mathrm{C}\right)$ and $\mathrm{pH}(5.0)$.

Screening for salinity tolerance was done where we found that Azo-144 was able to resists $5 \%$ solution of $\mathrm{NaCl}$ and at same time produced a fair amount of IAA $(34.04 \mu \mathrm{g} / \mathrm{ml})$, much less than its other three competitors. Similar results were obtained by Omer et al. (2016), who reported production of IAA under $1 \%$ concentration of $\mathrm{NaCl}$. Production of phytohormones activity was reduced drastically with increase in the level of salinity as was shown by Azo-144, which produced the lowest amount of IAA in comparison with other three isolates. Similar findings were reported by Paul et al. (2014) in Azotobacter chroococcum for three isolates when they were grown in $1.5 \mathrm{M}$ concentration of $\mathrm{NaCl}$.

\section{CONCLUSIONS}

Keeping in mind the rising obstacles in the form of abiotic stresses with respect to climate change, 
we must formulate a decisive plan to sustain free-flowing production in the agricultural sector. To truly unleash the untapped potential of Azotobacter sp. in the shape of a well-configured physical matter called biofertilizer for harsh climatic conditions, we must explore novel strains. A great deal of study into the understanding of its biophysical and physiological properties when grown under stress conditions needs to be highlighted in order to attain fully-fledged sustainability in the agricultural sector.

\section{ACKNOWLEDGEMENTS}

Author Ravindra Soni wants to acknowledge Chhattisgarh Council of Science and Technology, Chhattisgarh, for financial assistance.

Received 12 April 2017 Accepted 7 September 2017

\section{References}

1. Alsamowal MM, Hadad MA, Mohammed MA, Elhassan GA. In vitro study the characterization of Azotobacter spp. isolates from Sudanese soils. Journal of Agriculture and Research. 2016; 2(6): 47-56.

2. Becking JH. The family Azotobacteraceae. In: Starr MP, Stolp H, Triiper HG, Balows A, Schlegel HG, editors. The Prokaryotes, vol. 2. Berlin, Heidelberg: Springer Verlag 1981. p. 795-817.

3. Bergersen FJ. Measurement of nitrogen fixation by direct means. In: Bergersen FJ, editor. Methods for evaluating biological nitrogen fixation. New York: John Wiley and Sons. Inc.; 1980. p. 65-110.

4. Chennappa G, Naik MK, Adkar-Purushothama CR, Amaresh YS, Sreenivasa MY. PGP potential, abiotic stress tolerance and antifungal activity of Azotobacter strains isolated from paddy soils. Indian Journal of Experimental Biology. 2016; 54: 322-31.

5. Gomare KS, Mese M, Shetkar Y. Isolation of Azotobacter and cost effective production of biofertilizer. Indian Journal Of Applied Research. 2013; 3(5): 54-6.

6. Hogg S. Essential microbiology. Chichester, England: John Wiley and Sons Ltd. 2005.

7. Jadhav GG, Salunkhe DS, Nerkar DP, Bhadekar RK. Isolation and characterization of salt-tolerant nitrogen-fixing microorganisms from food. EurAsia J Bio Sci. 2010; 4(5): 33-40.

8. Jimenez DJ, Montana JS, Martinez MM. Characterization of free nitrogen fixing bacteria of the genus azotobacter in organic vegetablegrown Colombian soils. Brazilian Journal of Microbiology. 2011; 42: 846-58.

9. Jnawali AD, Ojha RB, Marahatta S. Role of Azotobacter in soil fertility and sustainability - a review. Advances in Plants \& Agriculture Research. 2015; 2(6): 1-5.

10. Khullar S, Chahal VPS. Distribution of Azotobacter in the Punjab soils. J Res. 1975; 13: 398-404.

11. Kumar GP, Ahmed SKMH, Desai S, Amalraj ELD, Rasul A. In vitro screening for abiotic stress tolerance in potent biocontrol and plant growth promoting strains of Pseudomonas and Bacillus spp. International Journal of Bacteriology. 2014. doi:10.1155/2014/195946.

12. Lineweaver $\mathrm{H}$. Characteristics of oxidation by Azotobacter. J Biol Chem. 1933; 99: 575-93.

13. Mali GV, Bodhankar MG. Antifungal and phytohormone production potential of Azotobacter Chroococcum isolates from groundnut (Arachis hypogeal L.) rhizosphere. Asian J Exp Sci. 2009; 23(1): 293-7.

14. Ninawe AS, Paulraj R. Effect of salinity on the growth and nitrogen fixation of Azotobacter Beijerinckii. Journal of Aquaculture. 2003; 11: 7-17.

15. Omer AM, Emara HM, Zaghloul RA, AbdelMonem MO, Dawwam GE. Potential of Azotobacter Salinestris as plant growth promoting rhizobacteria under saline stress conditions. Research Journal of Pharmaceutical, Biological and Chemical Sciences. 2016; 7(6): 2572.

16. Orhan F. Alleviation of salt stress by halotolerant and halophilic plant growth-promoting 
bacteria in wheat (Triticum aestivum). Brazilian Journal of Microbiology. 2016; 47: 621-7.

17. Paul S, Bandeppa Aggarwal C, Thakur JK, Rathi MS, Khan MA. Effect of salt on growth and plant growth promoting activities of $\mathrm{AzO}$ tobacter chroococcum isolated from saline soils. Environment \& Ecology. 2014; 32(4): 1255-9.

18. Rahmayani S, Hindersah R, Fitriatin BN. Role of Azotobacter sp. on nitrogen uptake and growth of soybean (Glycine max (L.) Merrill) on saline soil. International Journal of Scientific \& Engineering Research. 2017; 8(6): 1214-20.

19. Raju ME, Venkataraman CR, Arunachalam G. Relationship between Azotobacter population and certain physiological population of $\mathrm{Ta}$ mil Nadu soils (Abstract). In: Proceedings of the Tenth Annual Conference of the Association of Microbiologists, 1974; India.

20. Ravikumar S, Kathiresan K, Ignatiammal TM, Baba MS, Shanthy S. Nitrogen fixing Azotobacters from mangrove habitat and their utility as marine biofertilizes. Journal of Experimental Marine Biology and Ecology. 2004; 31(2): 5-17.

21. Sahoo RK, Ansari MW, Pradhan M, Dangar TK, Mohanty S, Tuteja N. A novel Azotobacter vinellandii (SRIAz3) functions in salinity stress tolerance in rice. Plant Signaling \& Behavior. 2014; 9:e29377; PMID: 24874118.

22. Sethi SK, Adhikary SP. Azotobacter: a plant growth promoting rhizobacteria used as biofertilizer. Dynamic Biochemistry, Process Biotechnology and Molecular Biology. 2012; 6 (Special Issue 1): 68-74.

23. Subramanian P, Kim K, Krishnamoorthy R, Mageswari A, Selvakumar G, Sa T. Cold stress tolerance in psychrotolerant soil bacteria and their conferred chilling resistance in tomato (Solanum lycopersicum Mill.) under low temperatures. PLoS ONE. 2016; 11(8): 1-17.

24. Suliasih. The effect of salt tolerant nitrogen fixing bacteria on the growth of paddy rice (Ory$z a$ sativa L.). Journal of Biological Researches. 2013; 19: 11-14.
25. Tejera N, Lluch C, Martinez-Toledo MV, Gonzalez-Lopez. Isolation and characterization of Azotobacter and Azospirillum strains from the sugarcane rhizosphere. Plant and Soil. 2005; 270: 223-32.

26. Thompson JP, Skerman VD. Azotobacteraceae: the taxonomy and ecology of the aerobic nitrogen-fixing bacteria. New York: Academic Press, Inc.; 1979.

27. Viscardi S, Ventorino V, Duran P, Maggio A, De Pascale S, Mora ML, Pepe O. Assessment of plant growth promoting activities and abiotic stress tolerance of Azotobacter chroococcum strains for a potential use in sustainable agriculture. Journal of Soil Science and Plant Nutrition. 2016; 16(3): 848-63.

28. Wani SA, Chand S, Ali T. Potential Use of Azotobacter chroococcum in crop production: an overview. Current Agriculture Research Journal. 2013; 1(1): 35-8.

29. Wu FJY, Moreno J, Vela GR. Growth of Azotobacter vinelandii on soil nutrients. Applied and Environmental Microbiology. 1987; 53(3): 489-94.

\section{Navin Kumar Nag, Biplab Dash, SB Gupta, Dharmendra Khokher, Ravindra Soni \\ AZOTOBACTER IZOLIATŲ ATSPARUMO STRESUI VERTINIMAS}

\section{Santrauka}

Aukštos temperatūros, $\mathrm{pH}$ ir druskingumo tolerancijos vertinimas buvo atliktas 50 Azotobacter izoliatų, iš kurių keturi izoliatai (Azo-48, Azo-137, Azo-144 ir Azo-160) buvo tolerantiški visiems trims rodmenims. Toleranciją $\mathrm{pH}(5,0)$ parodè 20 izoliatų, dauguma jų (75\%) toleravo ir temperatūrą. Atlikta 14-os atrinktų izoliatų kolonijų charakteristikų, biocheminių savybių, azoto fiksavimo pajègumo ir fitohormonų produkcijos analizè. Galiausiai, atlikus išsamų vertinimą ir kritinę analizę, buvo atrinkti anksčiau minèti keturi izoliatai, iš kurių vienas (Azo-144) toleravo gana didelị druskingumą.

Raktažodžiai: stresas, Azotobacter, tolerancija, biotrąšos 